natural- to human-dominated systemsa legacy that has ramifications for today's landscape. The ability of extreme events to cause steep changes in these landscapes, effectively changing the regional boundary conditions, should be seen as a warning for the potential impacts of extreme events in future climates. It also means that conventional modeling and assessment tools used for sustainable management strategies may be inadequate to accommodate legacies and complex interactions over decadal and centennial timescales because they generally don't integrate extreme events.

\section{Human-environment feedback}

In contrast to reconstructions of geomorphic and pedologic history, there are only a few studies concerning possible feedbacks from land use. These studies equate societal collapse to vulnerability to climate change, agricultural maladaptation or a mixture of both. For example, historical studies show that during the first half of the $14^{\text {th }}$ century, many villages in Germany were abandoned as an ultimate consequence of a combination of socio-cultural processes, crop failures and soil degradation (Bork et al., 1998; Dotterweich, 2008). Food prices became very expensive in several consecutive years of the first half of the $14^{\text {th }}$ century because of shortages as a consequence of soil degradation and economic mismanagement (Fraser, 2010). This unfavorable socio-economic, nutritional, and health situation might have prepared the ground for the Europeanwide pandemic, namely the Black Death, between 1347 and $1351 \mathrm{AD}$. In the $18^{\text {th }}$ to early $19^{\text {th }}$ centuries, soil erosion and crop failures led to major migration overseas. Soil erosion appears to have been one factor in a complex causality spiral leading to socio-economic instability and land-use changes.

\section{Modern day environments}

In light of historical and recent data (severe floods with high costs to our societies), we now have new insight into the interactions between societies and their environment. This type of research has the potential to help in the development of modern sustainable land-use strategies by providing evidence for the different timescales and complexity of interactions between human activities and geomorphic responses. However, many past studies combine and correlate different time series, assuming causality and neglecting the legacy of past forcings and responses. Future approaches must better distinguish proximate from ultimate causes to deliver a new understanding of complex system behavior. The research also has to extend the scope of analysis to the full spectrum of human-environment interactions including the demise of agriculturally marginal systems and the histories of more subtle, adaptive and cumulative changes and processes. This will extend our observation of background processes in modern human-dominated landscapes and their natural variability. Past records have an important role to play in the creation of adaption strategies for complex agricultural systems around the world.

\section{References}

Dotterweich, M., 2008: The history of soil erosion and fluvial deposits in small catchments of central Europe: Deciphering the long-term interaction between humans and the environment - A review, Geomorphology, 101(1-2): 192-208.

Dreibrodt, S., Lubos, C., Terhorst, B., Damm, B. and Bork, H.-R., 2010 Historical soil erosion by water in Germany: Scales and archives, chronology, research perspectives, Quaternary International, 222(1-2): 80-95.

Fraser, E.D.G., 2010: Can economic, land use and climatic stresses lead to famine, disease, warfare and death? Using Europe's calamitous $14^{\text {th }}$ century as a parable for the modern age, Ecological Economics, 70(7): 1269-1279.

Hoffmann, T., Thorndycraft, V.R., Brown, A.G., Coulthard, T.J., Damnati, B., Kale, V.S., Middelkoop, H., Notebaert, B. and Walling, D.E., 2011: Human impact on fluvial regimes and sediment flux during the Holocene: Review and future research agenda, Global and Planetary Change, 72: 87-98.

Notebaert, B. and Verstraeten, G., 2010: Sensitivity of West and Central European river systems to environmental changes during the Holocene: A review, Earth Science Reviews, 103(3-4): 163-182.

For full references please consult:

http://www.pages-igbp.org/products/newsletters/ref2011_2.pdf

\title{
Long-term perspectives on an iconic landscape: Origins and future trajectories of the "Ancient and Ornamental Woodlland", New Forest, UK
}

\author{
Mary Edwards ${ }^{1}$ and Michael J. Grant ${ }^{2,3}$ \\ ${ }^{1}$ Geography and Environment, University of Southampton, UK; M.E.Edwards@soton.ac.uk \\ Wessex Archaeology, Salisbury, UK; m.grant@wessexarch.co.uk; ${ }^{3}$ School of Geography, Geology and the Environment, Kingston University, UK
}

Paleoecology, in combination with more recent ecological observations and future climate projections, can play a key role in providing a robust basis upon which to build ecological management strategies for important biodiversity areas.

\section{The New Forest: Management dilemmas}

National parks in Britain are managed for multiple uses: they are often scenic areas and attract numerous visitors, they support local economies beyond tourism, particularly agriculture and forestry, and they are foci of biodiversity. Climate change introduces uncertainty to this challenging and sometimes conflicting land use mixture, and will affect management strategies for the $21^{\text {st }}$ Century. The New Forest (Fig. 1a), which lies just to the west of Southampton in central southern England, is one of the
UK's newest parks, and was established in 2005. Its landscapes and ecosystems give rise to outstanding lowland scenery and there are well-established amenity uses (it is only two hours from London). High levels of biodiversity, compared with the agricultural regions and urban areas that surround it, have attracted numerous national and European directives on species and habitat conservation. The medieval wood-pasture system maintained via customary rights and administered by a local court, is recognized as a unique cultural attribute that is closely linked with the For- est's ecology and landscapes. The future of the New Forest will depend upon the management strategies of government agencies, landowners, and the local user groups who practice customary rights such as stock grazing. Increasingly, it will depend upon the interaction of climatic factors and the constituent species of its ecosystems. The Forest features a range of highly valued habitats; here we examine one habitat type of high biodiversity and amenity value, the so-called "Ancient and Ornamental Woodland" (A\&O Woodland; Peterken et al., 1999; Tubbs, 2001; Fig. 1A). 

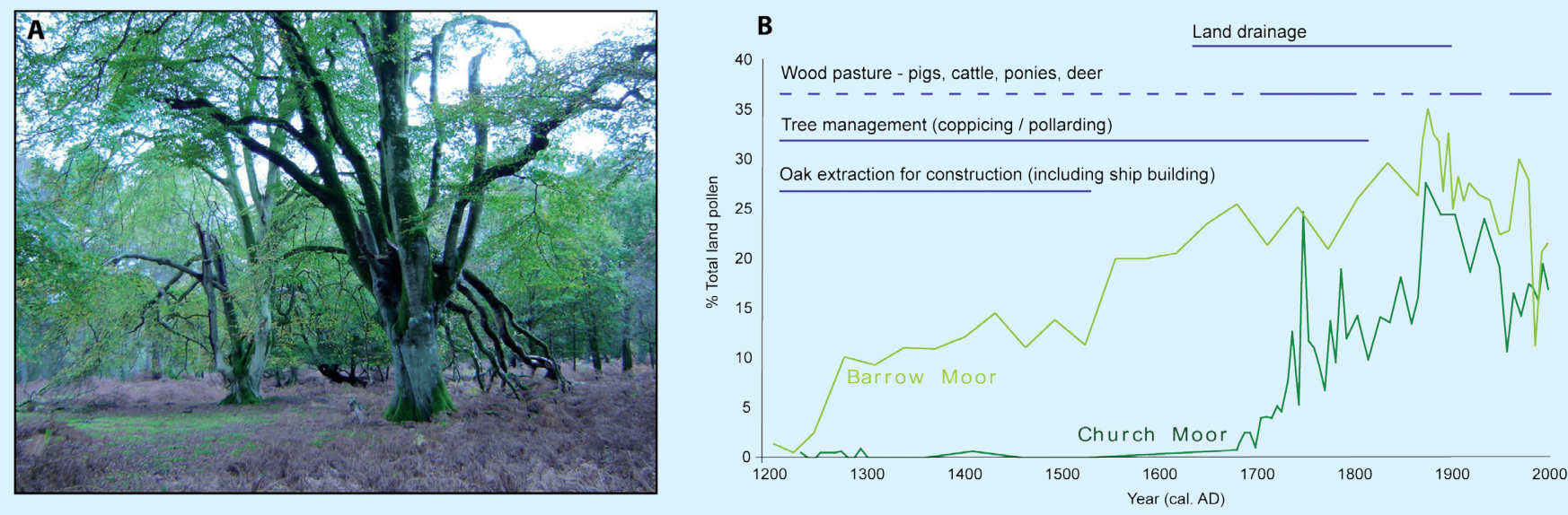

Figure 1: A) Typical A\&O Woodland featuring over-mature, previously pollarded beech trees (Photo M.J. Grant). B) Pollen percent curves for beech (Fagus) at two valley mire (peatland) sites, Barrow and Church Moor, located within Mark Ash Wood. Both curves are at their highest between ca. 1700 and 1900 AD and subsequently decline, however at Barrow Moor the initial increase in Fagus occurs several hundred years earlier than at Church Moor. The horizontal lines indicate past land use practices, dotted lines indicate less certain records.

The A\&O Woodlands form part of a mosaic that also contains open heath, grazed lawns and plantations, reflecting both traditional uses and more recent commercial forestry activities. The current dramatic appearance of many woodlands, typified by large, often over-mature, beech (Fagus sylvatica; Fig. 1A), is likely due to 100 years of abandonment that followed a period of intensive management. Formerly, beech was pollarded (cut above head height) in association with wood-pasturing, fuel and timber production (Rackham, 2003). A dilemma for managers is that many visitors appreciate the current appearance of the A\&O woodland, but ecologically and structurally the system is gradually being transformed. To be maintained in the longer term, it must undergo a managed regeneration cycle that will inevitably alter current conditions over the decades to come. Knowledge of the past cultural and environmental conditions that have led to the development of the current system can inform current management choices and provide a temporal perspective on the key question of whether long-term sustainability of this landscape and ecosystem is truly achievable (see Grant and Edwards (2008) for more details).

\section{Long-term record of beech}

Two valley mire deposits lying within $A \& O$ Woodland were selected for pollen studies: Barrow Moor and Church Moor, located $\sim 600 \mathrm{~m}$ apart from each other. The pollen record of Fagus (Fig. 1B) shows that it did not become a significant component of the woodland until a few hundred years ago and that its expansion was locally asynchronous. At both sites, expansion coincided with an increase in holly (llex aquifolium), the herbs Plantago lanceolata and Rumex spp., and bracken (Pteridium aquilinum), all indicative of increased grazing pressure, and a decline in hazel (Corylus avellana). This last development may relate to the deliberate removal of hazel, abandonment of coppicing (a traditional woodland management method where trees are cut at ground level) and a shift to wood-pasture, or increased grazing pressure. Selective removal of oak (Quercus robur), particularly for naval construction (Flower, 1980; Tubbs, 2001) and possibly enhanced drainage, also favored expansion of beech. The overall importance of beech appears to decline during the $20^{\text {th }}$ century at both sites. Thus beech dominance within the A\&O Woodlands is relatively recent, likely related to human intervention rather than natural processes alone, and is now decreasing.

Locally, ecological monitoring of New Forest A\&O Woodlands for up to 50 years reveals a clear decrease in canopy and understory extent, particularly for beech, which can be related to several processes: high grazing pressure limiting regeneration, direct removal of holly from some areas, death or stress damage to trees following the severe drought of 1976 and the

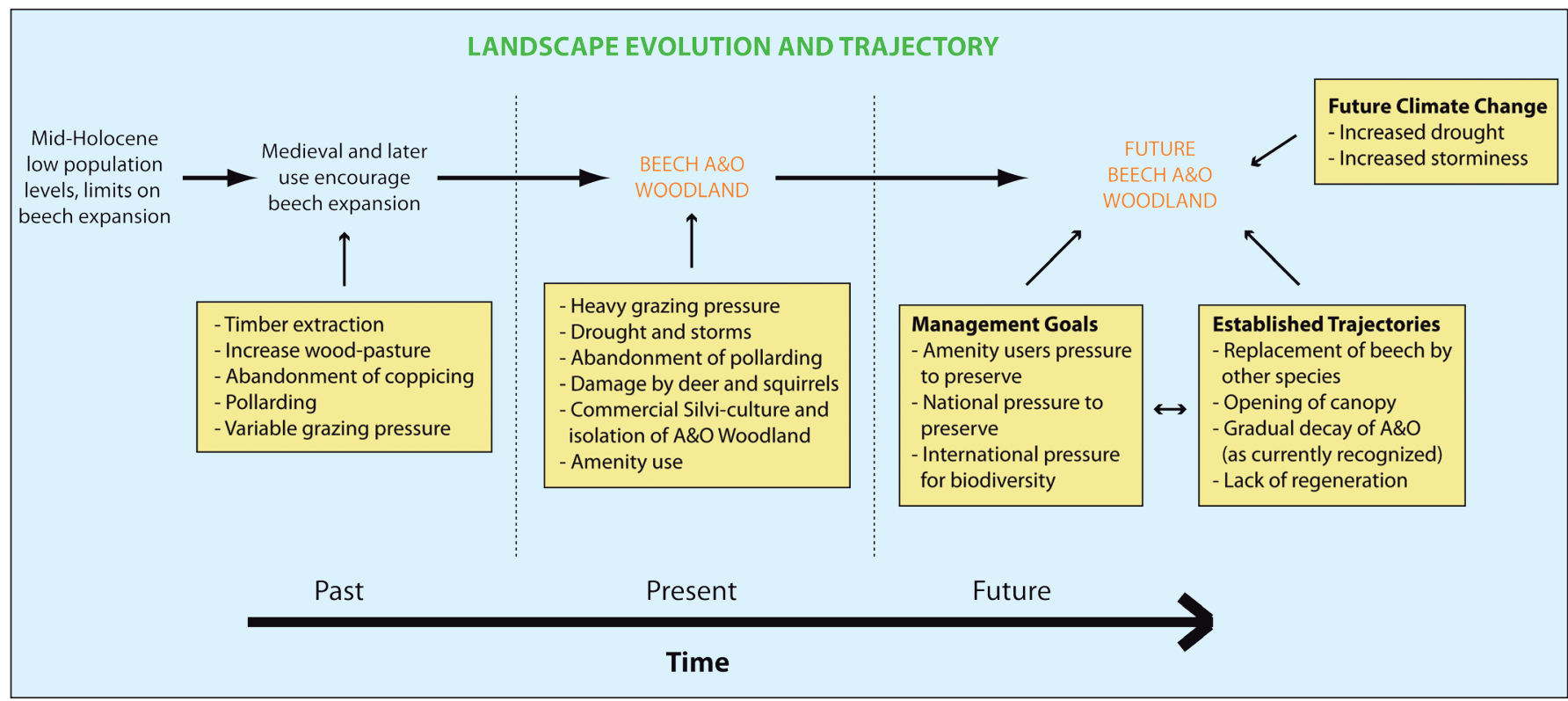


hurricane of 1987, and grey-squirrel damage (Mountford et al., 1999; Mountford and Peterken, 2003).

At broader spatial and temporal scales, the Holocene pollen sequence from Church Moor (Grant et al., 2009) and other localities in southern England indicate that beech was present as early as 6 cal ka BP, initially at extremely low abundance (1-2\%). Its expansion typically appears to be associated with anthropogenic activity in the late Holocene. In the High Weald area of southern Britain, south of London, beech expansion is also related to a change in land use, particularly to the adoption of the wood-pasture system (Waller and Schofield, 2006). Pannage (feeding by domestic pigs on acorns) may have particularly favored beech, as its seeds are highly dependent upon ground disturbance for establishment (Björkman, 1999; Watt, 1923).

\section{Future trends}

A combination of natural and humaninduced processes over the past several hundred years has led to the development of modern A\&O Woodlands as a New Forest landscape element. Figure 2 summarizes the drivers of past change, contemporary pressures and possible future for
A\&O Woodland. Sustaining the culturally generated structure and composition may require revival of the traditional management practices that formed the current landscape (or substitutes that achieve the same effect). The balance (or imbalance) between openness and regeneration reflects levels of grazing and browsing by stock and wild deer, and thus there is a role for stock and deer management. The current age structure already contributes to any future trajectory, and further opening of old stands within the present woodlands is inevitable. It will now be some time before a new generation of trees matures, irrespective of which management strategy is adopted. Furthermore, any longterm management intervention now also requires anticipation of climate-change pressures. For example, beech is susceptible to wind-throw, which will increase with projected greater storminess. Revival of pollarding on younger trees would mitigate wind-throw while also continuing a traditional past practice that underlies the structure and composition of contemporary $A \& O$ Woodland. On the other hand, projected levels of summer drought in the south of England may stress beech to an extent that it cannot thrive, in which case the woodland will follow a different tra- jectory and A\&O Woodlands as they are known today will eventually take on a new composition and appearance.

\section{Data}

More detailed accounts of the pollen data can be found in Grant and Edwards (2008) and Grant et al. (2009); the pollen data will be deposited with the European pollen database (www. europeanpollendatabase.net/) in due course and, until then, are available from M.J. Grant upon request.

\section{References}

Flower, N., 1980: The Management History and Structure of Unenclosed Woods in the New-Forest, Hampshire, Journal of Biogeography, 7: 311-328.

Grant, M.J. and Edwards, M.E., 2008: Conserving idealized landscapes: past history, public perception and future management in the New Forest (UK), Vegetation History and Archaeobotany, 17 551-562.

Mountford, E.P., Peterken, G.F., Edwards, P.J. and Manners, J.G., 1999: Long-term change in growth, mortality and regeneration of trees in Denny Wood, an old-growth wood-pasture in the New Forest (UK), Perspectives in Ecology, Evolution and Systematics, 2: 223-272.

Tubbs, C.R., 2001: The New Forest: History, Ecology and Conservation, New Forest Ninth Centenary Trust, 450pp.

Waller, M.P. and Schofield, J.E., 2006: Mid to late Holocene vegetation and land use history in the Weald of south-eastern England: multiple pollen profiles from the Rye area, Vegetation History and Archaeobotany, 16: 367-384

For full references please consult:

http://www.pages-igbp.org/products/newsletters/ref2011_2.pdf

\title{
Grazing activities and biodiversity history in the Pyrenees: New insights on high altitude ecosystems in the framework of a Human-Environment Observatory
}

\author{
Didier Galop ${ }^{1}$, T. Houet' ${ }^{1}$, F. Mazier ${ }^{1}$, G. Leroux ${ }^{2}$ and D. Rius ${ }^{1}$ \\ 'Laboratory GEODE UMR 5602 CNRS (GEOgraphie De I'Environnement), University of Toulouse, France; didier.galop@univ-tlse2.fr \\ ECOLAB UMR 5245 CNRS, University of Toulouse, France
}

\section{Reconstruction of the relationship between pastoral activities and vegetation history in the central Pyrenees demonstrates the importance of grazing pressure in the maintenance of floristic diversity in highland regions that have been abandoned.}

In the context of biodiversity management, as encouraged by the European Union Habitats Directives and by the implementation of national strategies, the preservation of traditional agro-pastoral farming activities (in particular extensive grazing), is a major issue acting to maintain or restore open land that is favorable to biodiversity. Here, we present a case from the Pyrenean Mountains, which is considered the most important mountainous massif in southern Europe due to its biodiversity and high levels of endemism. Since the mid $20^{\text {th }}$ century, agricultural activities in these mountains have signifi- cantly declined, often accompanied by a change in grazing practices. From a pastoral point of view, the current situation in the Pyrenees is complex. In the Eastern Pyrenees, grazing areas are being abandoned, which is resulting in an expansion of heathland and forest. Conversely, in the Central and Western Pyrenees, an intensification of grazing is observed. This intensification creates problems that are characteristic of overgrazed areas; soil erosion and the fragmentation of animal habitats by fences. European and national policies are attempting to face this situation, where over-grazing and abandonment co- exist, through support of conservation organizations, such as the Pyrenees national park, the regional natural parks, natural reserves, and nature charities, which participate in the local implementation of the networking program "Natura 2000" (Magda et al., 2001). The development of a comanagement structure, with involvement of local and governmental environmental managers, is encouraged in order to set up strategies reconciling biodiversity conservation with restoration or maintenance of agro-pastoral activities. Pastoral activities are considered essential for maintaining open land, preventing the expansion of 